\title{
TOWARDS CRITICAL EDITION OF LOLIMBARAJA'S VAIDYA-JEEVANA INCORPORATING THE IMPORTANT COMMENTARIES DEEPIKA BY RUDRABHATTA AND GUDARTHA DEEPIKA BY HARINATH GOSWAMI
}

\author{
Dr. Shrinath M. Vaidya \\ Professor,
}

Dept. of Ayurveda Samhita and Siddhanta, Sri Dharmasthala Manjunatheshwara College of

Ayurveda \& Hospital,

BM Road, Thannirhalla,

Hassan-573201,

Karnataka

\author{
Dr. Pratibha V. Kulakarni \\ Professor, \\ Dept. of Shareera Kriya ,
}

Sri Dharmasthala Manjunatheshwara College of

Ayurveda \& Hospital,

BM Road, Thannirhalla,

Hassan-573201,

Karnataka

Article DOI: https://doi.org/10.36713/epra5661

\begin{abstract}
The manuscripts preserved acts as valuable treasure of knowledge which can be utilized for the wellbeing of present generation as well as to pass on to the next generation. A thorough study on Deepika and Gudartha Deepika commentaries on Lolimbaraja's Vaidya jeevana, present in the form of manuscript in oriental research institute libraries has been brought much information that is new for present understanding. The present study focuses on treatment aspects of various diseases and preparation of yogas with easy available drugs in present clinical practice and better development of Ayurvedic practices. The study is based on the technical method of critical edition in order to update \& conserve the medical knowledge dealt in Deepika and Gudartha Deepika commentaries on Lolimbaraja's Vaidya jeevana.
\end{abstract}

Objective: 1. To collect and decipher two important commentaries on Lolimbarajas vaidya Jeevana

2. To collate and critically edit the two important commentaries on Lolibarajs Vaidya Jeevana to know their contributions.

Methodology

The study is based on seven plus five (total 12) manuscripts and all were in Devanagari script and their details are as below.

1. R-1 to $R 7$ are - Obtained from BORI, Pune : Acession numbers as - 1093/ 1886-92, 463/ 1895-98, 353/ 1879-80, 948/ 1891-95, 178/1882-83, 618/ $\mathrm{Vi}^{3 / 4}-1,306 / \mathrm{Vi}^{3 / 4.1}$

2. H-1 to H 4 are -Obtained from BORI, Pune; Accession numbers as- 462/1895-98, 913/ 1887-91, 635/ 1895-1902, 238.B/A 1883-84 and IX

3. H-5 - Obtained from Zen library, Arrah, Bihar; Accession number 76/42.

Digitization of manuscripts, editing and analysis of mutual relationship among collected copies of Manuscripts, transliteration of all extant of copies selected for Critical edition and Critical Edition with English Translation of the Text is being done.

\section{Conclusion}

By observing all internal and external evidences, Deepika by Rudrabhatta and Gudartha Deepika by Harinatha Goswami are the well known commentaries on Lolimbaraja's Vaidya jeevana pertaining to early and late 17th CAD respectively. These all contributions enhance the richness of Ayurveda in modern era.

KEYWORDS: Critical edition, Deepika, Rudrabhatta, Gudartha Deepika, Goswami Harinatha, Vaidya Jeevana, etc. 


\section{INTRODUCTION}

Deciphering a manuscripts and its critical edition for publication is a journey to re-observe the study material in an authentic experimentation and thereby make a conclusion. These conclusive factors of the contextual text are prepared through the series of unexplored and unidentified thoughts. The evaluation of the thought process is rightly to be well acquainted in the modified form without varying the meanings or keeping the meanings in its real form. A comprehensive and compact clarification is essentially incubated through the processing of the transcription of knowledge ${ }^{1}$.

The medical text is different from the other literary texts and therefore its extension is rhythmically supplemented by verification of the context considering the different log rhythms. The meaningful progression either in qualitative or quantitative perspective signifies the amplitude of the extensive and ample rectification of the context, if necessary. The substantiate tunes of the textual knowledge flows from time immemorial and accordingly enrich the queries of the researcher for further exploration. The present work is also taken to serve the same purpose.

Lolimbaraja was son of Divakara bhatta and native of Junnar of Pune district of Maharashtra state. He has composed many books through the conversation with his wife Murasha, who was renamed as Ratnaprabha by Lolimbaraja after marriage.

Lolimbaraja has written four books on Ayurveda and few books in Marathi on different subjects. Among the Ayurveda books Vaidyajeevana is the most popular because all its verses are lyrical, full of pun and fun. In these verses the author has described some common diseases briefly and prescribed medicine for them.

In view of its popularity many commentators namely Prayagadatta, Damodara, Rudrabhatta, Harinath have written their commentaries, out of which the following commentaries are found viz.,

1. Deepika by Rudrabhatta son of Koneri Bhatta resident of the town Khadder on the banks of river Godavari. Koneri Bhatta was court physician of Abdul Rahim Khankaana (15571630).

2. Gudhartha deepika by Goswami Harinath, son of Manohara and native of Kashmir. He is assigned to 1730 A.D.
3. Vidvadvaidya ranjani

4. Krishnapanditeeya

5. Deepika by Sukhananda ${ }^{2}$.

Time of Lolimbaraja - His name is uttered by Trimalla Bhatta in Yogatarangini. The time period of Trimalla bhatta is 1650. In Kashi Hindu Vishwa Vidyalaya a manuscript on Vaidya jeevana is available dated 1656. So lolimbaraja occupies place between Bhava mishra and Trimalla bhatta i.e the early part of $17^{\text {th }}$ century. Probably his time period can be fixed as 1625 A.D ${ }^{3}$.

Ayurveda has no limit. Researchers, commentators and compilators on the basis of their wisdom use to present their works for better acceptance time to time. So did the present scholar. The everflowing wisdom of ancient medical texts are meta morphically analyzed with the thoughts of different commentators of different times and with the logical reasoning. The confinement of any subject, particularly of the medical text, is not desirable at any stage in any aspect. The extensive study of any subject is fulfilled right from the outlook of the grammar, meter up to the nano-analysis of the content of subject matter. Considering this, analytical views from all possible angles are presented along with different annotations and indexing ${ }^{4}$.

To fulfill the above all aspects the present Research work is undertaken.

\section{Objective:}

1. To collect and decipher two important commentaries on Lolimbarajas vaidya Jeevana

2. To collate and critically edit the two important commentaries on Lolibarajs Vaidya Jeevana to know their contributions.

\section{Methodology}

SOURCE FOR CRITICAL EDITION:

The present manuscript is obtained from two sources such as

1. D.K. Jain Oriental Research Institute, Ara, Bihar. And

2. Bhandarkar Oriental Research Institute, Pune. Its list is as below 5 


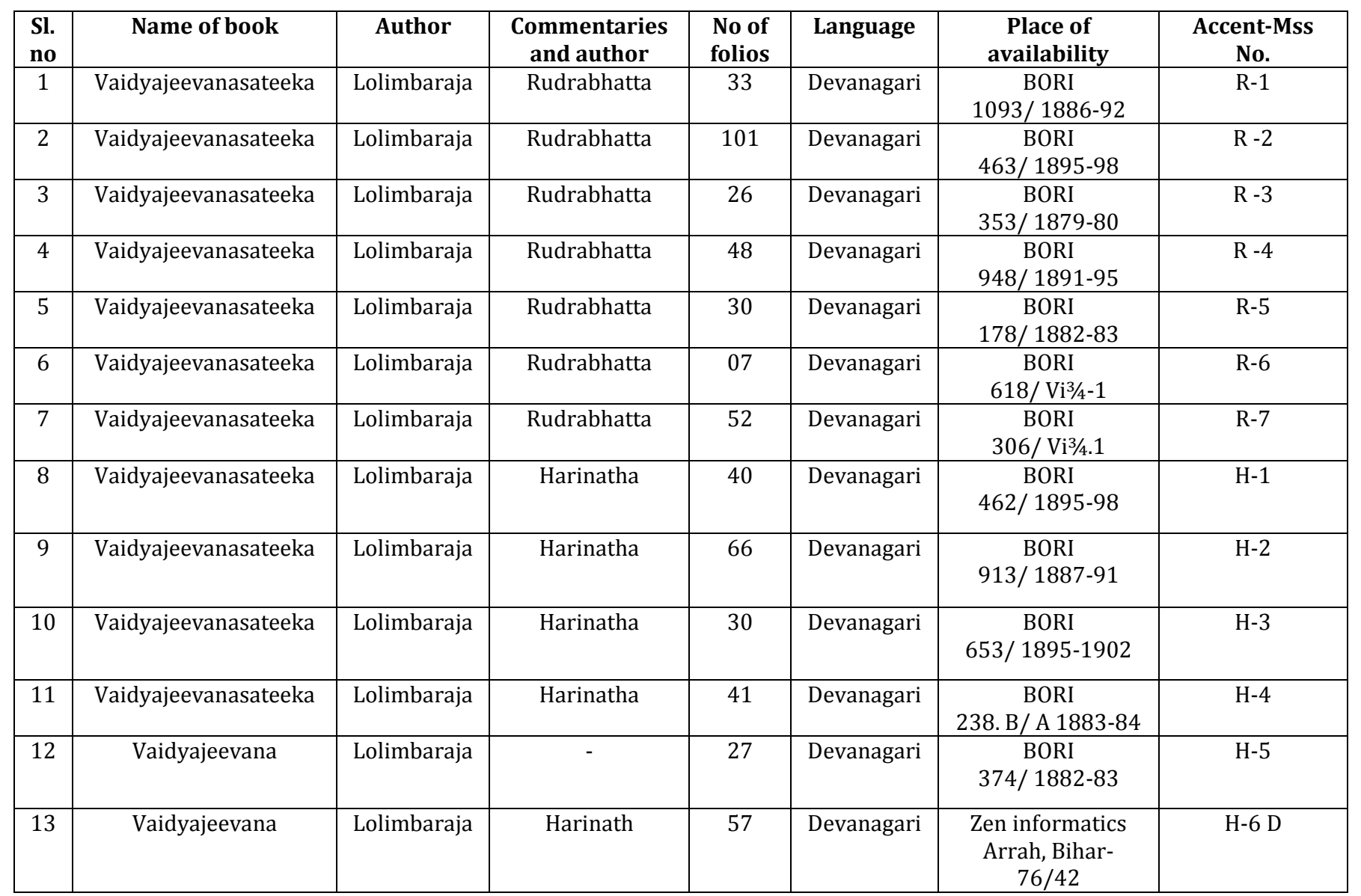

Note :

Sigla (special identification mark given to codex) - RDenotes - Lolimbaraja with Rudrabhatta commentary (Deepikia) of BORI

Sigla - H- Denotes - Lolimbaraja with Harinath commentary (Goodhartha deepika) of BORI

Sigla -H-6 D- Denotes -Lolimbaraja with Harinath commentary (Goodhartha deepika) of Arrah, Bihar are being utilized to compare Rudrabhatta and Harinath commentaries on Lolibaraja's Vaidya jeevana.

\section{RUDRABHATTA, STYLE AND} NARRATION

The Vaidyajīvana takes the form of a conversation between the narrator and his mistress, as we are explicitly told at the end of the fifth vilāsa. The narrator is identified as the author at several places but we are given no real idea of who the lady in question is. Lolimbarāja spends much time elaborating on her beauty, and she is clearly his lover, but he also refers to her as g»hi's ('lady of the house') which perhaps suggests she is his wife. She is often addressed as 'Ratnakalā' and it is said that Lolimbarāja married a daughter of a Muslim to whom he later gave this name. His addresses and admonitions to her - through which we learn about her and their relationship; her voice is rarely heard, one such instance being this verse -
Poet -mÉëÉhÉånÉUåå İmÉërÉiÉqÉå,

P- ÌMüÇ uÉSÉÍqÉ,

$P$-iÉîiMüqÉÑ qÉ×aÉÉÍøÉ,

P - xÉqrÉMçü zÉ×hÉÑ mÉëhÉİrÉÌlÉ,

The commentator tells us that the work is elaborated with the question and answer (praśnottara)
Beloved -uÉS,

B - iÉiMüÉliÉ,

B - rÉŜ̂alÉMüÉËU,

B - mÉëhÉİrÉlÉç zÉ×hÉÉåÍqÉ,

format popular in Sanskrit literature (he also though tells us that it consists of prose and verse - gadya and 
padya - although there is only one very short prose part which appears to be an interpolation). The author does at one point ask the lady, "why do you keep asking me..." (2.4) about the use of a certain drug to cure a disease, but in fact it is a one way conversation punctuated only by rhetorical questions. Having an internal audience of course allows you to indirectly address your external audience. Thus when the lady's attention starts to flag, Lolimbarāja urges her - and us, the readers - to listen to his words.

The text is almost entirely dedicated to a description of various drugs prescribed for various diseases and their symptoms. It is thus much narrower in scope than the 'three great texts' of Ayurveda: the Caraka Samhita, Suśruta Samhita and A $1 \frac{1}{2} i \bar{a}$ ñgahrdaya. The prescriptions provided are short on detail. Only in a few places does Lolimbarāja note the quantities of each ingredient and he rarely describes how the drug should be prepared. A more typical verse, for example, is:

\section{sÉÉàIWûiÉcÉlSIÉmÉCMükÉÉlrÉÉ ÍNû̉ÉÂWûÉİmÉcÉÑqÉlSMüwÉÉrÉÈ | \\ İmÉ“ÉMüTüeuÉUSÉWûİmÉmÉÉxÉÉ uÉÉÎliÉİuÉlÉÉzÉWÒûiÉÉzÉMüUÈ xrÉÉiÉç ||22||}

The instructions given would thus only really be useful for someone who already had a good idea of how to prepare such medicines and perhaps such a knowledge, derived from Caraka and so on, is presupposed.

The author, more than once, extols the virtues of following dietary principles to stay healthy as in the verse 1.10 where medicine is said to be of no use if a patient was following the prescribed diet (pathya) and if the patient wasn't following the right pathya then medicine would be ineffective. The commentator has seen in this verse a gomutrika bandha, a type of citrakāvya (figurative poetry). Whether or not this was intended, the Sanskrit construction, which makes both lines sound identical, adds to the rhetorical effect of such grand statements.

We can perhaps explain the several references to women as a cure for various illnesses by the same reasoning. As with the worship of divinities, turning to women to restore your health is not without precedent in the Ayurvedic tradition. In śiśirartu - late winter or early spring - embracing a woman is a good remedy for the cold. Lolimbarāja, though, is unusual in suggesting that young beautiful girls, in addition to many traditional seasonal delights (and generally not those of śiśira) such as the cuckoo's song, can cure a disease such as a pitta jvara. He twice tells us that drinking the nectar of your lover's lip is a substitute for, or even better than, the traditional medical remedy for a disease.

Kāvya intrudes in many other ways too, most plainly in the long and elaborate addresses to Lolimbarāja's lover. It is not unusual to find three fourths of a verse dedicated to a set of complex vocatives followed - often rather bathetically - by a quick note on which medicine will cure diarrheoa. For example:

qÉ×aÉqÉSİuÉsÉxÉssÉsÉÉOûqÉkrÉå

qÉ×aÉqÉSWûEEËUÍhÉ sÉÉåcÉlÉréålé |

qÉ×aÉlÉ×mÉiÉlÉÔSËU Îx§É

İmÉ"ÉeuÉUqÉmÉWû̂̂liÉ cÉ UæhÉuÉÈ MüwÉÉrÉÈ $\|18\|$

Plants too sometimes find mention less for their medicinal properties than their beauty. A description of the śyāma creeper (2.10), for instance, adds its medicinal use almost as a footnote, and a verse on the bakula tree (4.28) - a favourite of poets, particularly in descriptions of vasanta (spring) - seems to have no medical information at all.

Ala $\pm k_{i}$ ras (figures of speech), as well as a prahelikā (riddle), are also used, and in particular the upamā (simile) where the author draws on a range of natural, mythological and poetic examples to explain the action of a particular drug or disease. Sometimes these serve more to entertain than to enlighten, eg:

İuÉsÉÉÍxÉlÉİİuÉsÉÉxÉålÉ İuÉsÉÉÍxÉWØûSrÉÇ rÉjÉÉ|

iÉjÉÉ aÉÑQÕôcÉİİuÉ $\mu$ ÉålÉ

WûUåSÉqÉxÉqÉÏUhÉqÉç ||23\|

And at one point (1.69) he offers himself as the standard of comparison in an upamā (simile) where a particular drug removes viśama jvara just as he rolls at his lover's feet to remove her anger.

We find further evidence of this desire to enliven the text in the author's constant efforts to vary the vocabulary and syntax, for instance the use of the expression 'hartā bhavet' to avoid a repetition of 'harati/pariharati'. He also uses a great deal of synonyms, both for plants and diseases. Thus we have 'hanumaj-janaka-jvara', literally a 'Hanuman's-fatherjvara' or 'vāta-jvara' because Hanuman's father is of course the wind, vāta. 


\section{TRANSMISSION OF THE TEXT}

\section{Manuscript}

This edition is based on a seven manuscript of the Vaidyajīvana, obtained from different sources with their details are as given above.

Adhikarana

1) Prathama Vilasa

2) Dviteeya Vilasa

3) Truteeya Vilasa

4) Chaturtha Vilasa

5) Panchama Vilasa
29 shlokas(verses)

Shloka no.

82 shlokas (verses)

47 shlokas (verses)

45 shlokas (verses)

24 shlokas (verses)
There are five chapters Named as 'Vilasa;

\section{Contents}

Various concepts like Vaidya karthavya, Pathya, Mudavaidya tiraskara, Doshavaishamya-samyata, Jvara types and its treatment

Udara, Atisara, jvaratisara, Grahani, Sangrahani

Kasa and Shvasa

Kshaya and other diseases like shotha, pama, vyanga, daha, trushna.

Vajikarana, Rasayana yogas and Rasashoudhis and agrya aushadhis

\section{ABOUT THE COMMENTARY DEEPIKA BY RUDRABHATTA ABOUT THE COMMENTATOR, TIME AND PLACE:}

According to the internal evidences in the manuscript, we can assume that author (commentator) of this text as Rudrabhatta. He hails from the place at the junction of Godavari and Sindhu, resides on the banks of river Godavari admist Shatlekhaka named village.
Rudrabhattas family was known for knowledge of Ayurveda. He says that his ancestor named Krishna has written a commentary on Charaka samhita. His father Koneribhatta was in royal scribe in the palace of Abdur rahim Khankhana (1556-1623). His father was named as "Chiranjeeva". Rudrabhatta says that he has written commentary on five texts. This Deepika commentary on Lolimbaraja was composed by the order of King Mirja Khan. Mirja Rahim was named as Abdur rahim Khankhana by King Akbar. Lolimbaraja was equivalent to King Akbar. So Koneribhatta was at the same time of King Akbar.

\section{Family of Rudrabhatta}

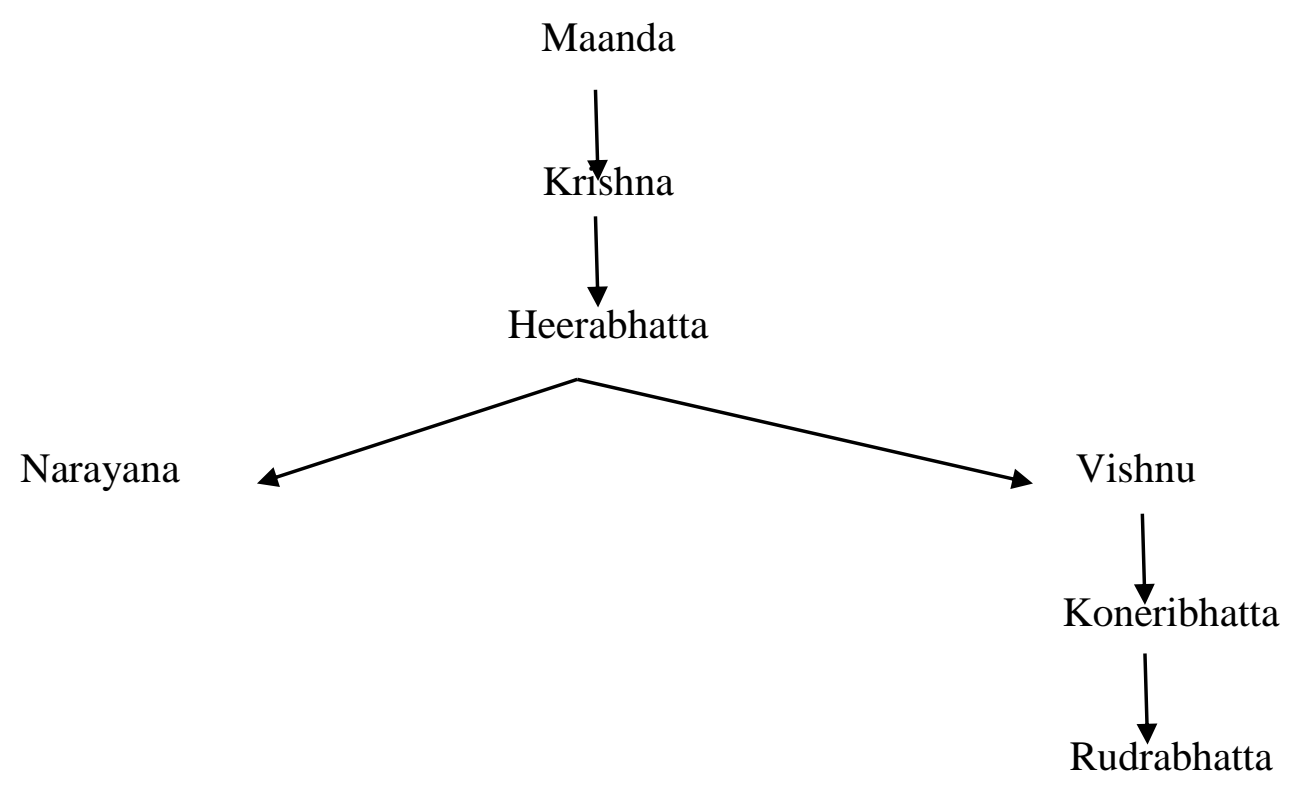




\section{Date}

Lolimbaraja pertails to mid of $16^{\text {th }}$ century and initial of $17^{\text {th }}$ century. The commentary of Rudrabhatta named Deepika is first on Lolimbaraja. So by this and even by internal and external evidences the time period of Rudrabhatta can be place at initial part of $17^{\text {th }}$ century ${ }^{7}$.

\section{Other works of author:}

\section{The Scribe, Style, Errors and Peculiarity:}

The manuscript suffers from a variety of mistakes, including:

- Scribal errors:

- Of syllables: eg: in $\mathrm{R} 1, \mathrm{R} 2, \mathrm{R} 3, \mathrm{R} 4$ $\mathrm{a}^{1 / 2 \mathrm{ila}}{ }^{-}$for akhila ${ }^{-}$in the commentary on 1.5

- Of repeated words or parts of words, eg: R $5, \mathrm{R} 6$ and $\mathrm{R} 7$ asati in the commentary on 1.10 is repeated unnecessarily

- Spelling errors, eg: s for ś, omission of $\mathrm{c}$ in eg: icchā. At times whole words are repeatedly misspelt, for instance ' $3 / 4 \mathrm{u}^{3} \mathrm{c} h \S$ ' (ginger) which appears as $\mathrm{su}^{3} \mathrm{th} \S, \mathrm{su}^{3} \mathrm{i} \mathrm{h} \S$ and so on.

- Sandhi errors, particularly visarga and anusvāra sandhi

- Grammatical errors, eg: R -1, R-3, R-5, R- 6 sevet for seveta

- Omissions:

- Of letters or parts of words, eg: m»gan»patanÀdari for m»gan»patitanÀdari $(1,25, .18)$

- Of words, eg: 1.2. 3. 4. 5. 1 the last element, '-tara \pm gail' the end of the verse has been omitted.

- Metrical errors: Eg, in the execution of p»thv§ meter, 5, 4, 7, (part 2).

- Misquoted excerpts (only found in the commentary), eg: a corruption of the well known phrase eÉÉiÉÉæ eÉÉiÉÉæ rÉSÒiM $\times \ddot{u ̈}^{1} C$ iÉSè U|ÉqÉÍpÉkÉÏrÉiÉå is found in the commentary on 1.2.3.4. 5.7./ 2

It is not possible to ascertain whether all or some of these are errors committed by the author and commentator, or by a scribe at some point in the text's transmission or by the lithograph printer. Unfortunately it was not possible to obtain another manuscript to better understand the source of the errors and to work towards a critical edition.

\section{Peculiar words}

No such of peculiar word are found in the mss.

Language

Marginal writings and inter linear additions of R-1, R-2 \& R-5 Mss. and In R- 7 Marginal writing is present in Hindi script.

Different Yoga- Ekamulika prayoga, Rasoushadhi Lepa, Kashaya and various Paana and yogas and are the specialty of Deepika commentary, along with it all other kinds of preparations are also explained.

Method of Preparation-The author has used different method of preparation for little yoga.

Use of various Synonyms-The author has used various synonyms for herbal as well as mineral drugs for easy understanding that are having a specific root meaning and useful in understanding the drug accurately.

\section{Emendations and Corrections}

To avoid excessive footnotes, we have corrected commonly occurring mistakes (Eg: Incorrect use of s, ś) and mis-spelt words $\left(\mathrm{Eg}:{ }^{3} / 4 \mathrm{u}^{3} \mathrm{th} \S\right)$ in the text without comment.

Where it was certain beyond doubt what the correct word or phrase should be, we have emended the text and added a footnote giving the original, incorrect reading.

In all other places, we have preserved the original, incorrect reading and added a suggested emendation in the footnote.

\section{Publications}

The Vaidyajīvana has been published as part of the Krishnadas Ayurveda series by the Krishnadas Academy. It includes an English translation by Nirmal Saxena.

\section{GUDARTHA DEEPIKA BY HARINATHA GOSWAMI I:}

A total of five manuscripts were collected from Oriental Research Institutions and manuscript libraries from India i.e from BORI-Pune, Zen library Arrah, Bihar and their details are given above.

Gudartha Deepika contains five Vilasa as, 


\section{BRIEF CONTENTS OF WHOLE GUDARTHA DEEPIKA:}

There are five chapters Named as 'Vilasa;.

Adhikarana

1) Prathama Vilasa

2) Dviteeya Vilasa

3) Truteeya Vilasa

4) Chaturtha Vilasa

5) Panchama Vilasa

In Vaidya Jeevana, easily available and very practical formulations with respect to the diseases and Vajikarana and Rasayana are documented. Critical edition and translations of the concepts is need of the hour. Need of the hour is met by critically editing it, for the recognition of its contributions of the Harinatha Goswami in understanding of original text Vaidya jeevana to the treatment of all diseases by using single and multiple drugs for better practice. Gudartha Deepika by Harinatha Goswami commentary on Lolimbaraja's Vaidya jeevana is critically edited by acquiring all possible manuscripts present with the name cited above. Researchers and commentators based on their wisdom; use to present their works for better acceptance from time to time, so did present scholar in writing Gudartha Deepika. The ever-flowing wisdom of the ancient medical text is Metamorphically analyzed with the thoughts of different commentators of different times and with the logical reasoning and presented with the best possible ways.

\section{SOURCE}

There are five manuscripts obtained for the study, all the copies of the text for its availability was identified using Descriptive catalogue of Sanskrit manuscripts published by BORI, Poona in 19391, Sanskrit medical manuscripts in India published by Central Council for Research in India Medicine and Homeopathy $^{8}$, New Delhi and New Catalogous Catalogorum published by University of Madras; 1968. Vol $2^{9}$ their details are given above.

\section{ABOUT THE COMMENTARY GUDARTHA DEEPIKA BY GOSWMI HARINATHA ABOUT THE COMMENTATOR, TIME AND PLACE}

According to the internal evidences in the manuscript, we can assume that author (commenatator) of this text as Harinatha Goswami. He is son of

\section{Contents}

Various concepts like Vaidya karthavya, Pathya, Mudavaidya tiraskara, Doshavaishamya-samyata, Jvara types and its treatment

Atisara, jvaratisara, Grahani, Sangrahani

Kasa and Shvasa

Kshaya and other diseases like shotha, pama, vyanga, daha, trushna.

Vajikarana, Rasayana yogas and Rasashoudhis and agrya aushadhis

Manohara and grandson of Lakshmi Das. He learnt the Haripradhana Dharma by Goswami. Surname of Harinatha as 'Sharma' ${ }^{10}$.

In H-4 scribe has mentioned as Harinatha was from the area named Kushpur (Kashmira??) which was on the bank of Vaitastya (River) ${ }^{11}$, the modern name of Vitasta is Jhelum has been adopted from the city of Jhelum. This river flows near border of Kashmir and Pakistan.

\section{DATE}

The exact period of author cannot be fixed, nowhere in Mss Mentions about author time period. As per the internal and external evidences, the time period of author can be fixed at 17 th CAD. Harinatha assigned to the period of 1730.A.D.

OTHER WORKS OF AUTHOR: No any other works are found by the name Harinatha Goswami.

THE SCRIBE, STYLE, ERRORS AND PECULIARITY:

$\mathrm{H} 1, \mathrm{H} 3$ are having Commentary above and below the main verse and in middle main verse is given, whereas $\mathrm{H} 2$ and $\mathrm{H} 4$ are commentary continues with main verses. H 5 having only Main verses, not commentary part.

Scribe has defaced the deleted matter with the ink. Errors/missing letters or words are corrected by simple insertion. Few shlokha numbers are missing/ miss placed. Few are of transposition, orthographic peculiarities. Where alpakshara is present, scribe has corrected by placing ' $\mathrm{m}$ ' and 'I'' over letter over the letter to make it deergakshara..In the place of 'oÉÉåsÉÉ' the scribe has written

The common scribal errors found in

Usage of 'LÉÉ' in the place of ' $h E ́ E$ ',

Usage of ' $\mathrm{mE}$ ' in the place of ' $\mathrm{rE}$ ',



Usage of 'uE' in the place of 'oÉ',

Usage of 'Nû' in the place of ' $j E$ ',

Usage of ' $x E$ ' in the place of ' $z E$ ',

Usage of '®É' in the placeof ' $k E ́ E ́$ ' 
H-4 - Usage of 'YMüû' in the place of 'NÉ', Peculiar words

No such of peculiar word are found in the mss.

Language

The Sanskrit language is used in all manuscripts of Gudartha Deepika. Sanskrit is an enriched and scientific language for the absolute expression of thoughts and ideas and therefore, this language was also used in writing or studying of the medical texts to codify the contents within a brief and to enact within the reach of the human intellect.

Marginal writings and inter linear additions of $\mathrm{H}-1, \mathrm{H}-3$ \& H-4 Mss. and In H-4 Marginal writing is present in Hindi script.

Different Yoga- Kashaya, Lepa,various Paana and Rasoushadhi yogas and ekamulika prayoga are the specialty of Upacharasara, along with it all other kinds of preparations are also explained.

Method of Preparation-The author has used different method of preparation for little yoga.

Use of various Synonyms-The author has used various synonyms for herbal as well as mineral drugs for easy understanding that are having a specific root meaning and useful in understanding the drug accurately.

\section{Publications}

No any publications found till date on this commentary.

\section{CONCLUSION}

Vaidya Jeevana text is easily available and in it very practical formulations with respect to the many diseases with Vajikarana, Rasayana and Agryoushadha are documented. So the need of critical edition is met by critically editing the commentaries on it namely Deepika by Rudrabhatta and Gudartha Deepika by Harinatha to know the treatment of various diseases by using single and multiple drugs for better practice in present era.

Deepika by Rudrabatta a beautiful commentary on Lolimbaraja's Vaidya jeevana has given his geneology as grand son of Vishnu and son of Koneri Bhatta. He has mentioned his place as a beautiful city "Satkshetaka" situated on the banks of river Godavari near its confluence with Sindhu. His father was Koneri bhata and grand father was Vishnu. He states that Krishna named person in his family has written a commentary on Charaka Samhita.

Gudarthadeepika by Goswami Harinatha commentary on Lolimbaraja's Vaidya jeevana deals with elaborate and easy explanation of each verses of Vaidya jeevana text.Being a commenatary on Vaidya jeevana, the author comments and helps in easy understanding of the original text.
The text explains treatment for sixty diseases. All of these are described systematically in fiveVilasa (chapters) of Vaidya jeevana with unique manner.

Rudrabhatta mentiones his time period in the commentary Deepika as close to as King Abdul Rahim Khan (1556-1626). Rudrabhatta tells that as per direction of Khana Khana (another name of Abdul Rahim Khan given by King Akbar) the Deepika commentary was being composed by him. And even from external and internal evidences suggest to assign the time period of Rudrabhatta as initial part of $17^{\text {th }}$ century

According to external and internal evidences time period of author Harinatha assigned to the period of 1730.A.D. He was son of Manohara and grandson of Lakshmi Das. He learnt the Haripradhana Dharma by Goswami. Harinatha's Surname is used as -'Sharma'

So both the commentaries viz. Deepika Rudrabhatta and Gudarthadeepika by Goswami Harinatha on Lolimbaraja's Vaidya jeevana helps in better understanding of diseases as well as their treatment application in day today clinical practice.

\section{REFERENCES}

1. Sharma HD. Descriptive Catalogue of Sanskrit manuscripts. $1^{\text {st }}$ edition. Poona: Bhandarkar Oriental Research Institute; 1939:p.33-36.

2. Rama Rao B.Sanskrit Medical Manuscripts in India.New Delhi: Published for the Central Council for Research in India Medicine and Homeopathy; 1972: p.64.

3. Raghavan V.New CatalogousCatalogorum. Revised edition. Madras: University of Madras; 1968:Vol II.p.345.

4. Sharma PV. Ayurveda ka vaijnanikaitihasa. $7^{\text {th }}$ edition. Varanasi: Choukhambha Orientalia; 2003: p.341

5. Ibid, p.339

6. Sharma $P V$. Vaidyajeevanam. $1^{\text {st }}$ edition. Varanasi : Choukhambha Sanskrit Pratishtan; 2005: p.10-12

7. Ibid, p.339-340

8. Rama Rao B.Sanskrit Medical Manuscripts in India.New Delhi: Published for the Central Council for Research in India Medicine and Homeopathy; 1972: p.64.

9. Raghavan V.New CatalogousCatalogorum. Revised edition. Madras: University of Madras; 1968:Vol II.p.345.

10. Sharma PV. Ayurveda ka vaijnanikaitihasa. $7^{\text {th }} e d$. Varanasi: Choukhambha Orientalia;2003:p. 339

11. Murthy RSS. Introduction to Manuscriptology. $1^{\text {st }}$ ed. Delhi: Sharada publishing House; 1996:p. 160,163 . 